\title{
Desert locust outbreaks in the Sahel: resource competition, predation and ecological effects of pest control
}

\author{
JOSÉ A. SÁNCHEZ-ZAPATA,* JOSÉ A. DONÁZAR,† \\ ANTONIO DELGADO, $¥$ MANUELA G. FORERO,†OLGA CEBALLOS $†$ \\ and FERNANDO HIRALDO† \\ *Department of Applied Biology, Universidad Miguel Hernández, Ctra de Beniel km 3.2, 33012 Orihuela, Alicante, \\ Spain; †Department of Applied Biology, Estación Biológica de Doñana, CSIC, Avda M ${ }^{a}$ Luisa s/n, 41013 Sevilla, \\ Spain; and $\ddagger$ Estación Experimental del Zaidín, CSIC, Profesor Albareda 1, 18008 Granada, Spain
}

\begin{abstract}
Summary
1. The desert locust Schistocerca gregaria has been considered a major pest since ancient times, as locust swarms holding millions of insects move throughout the Sahel, northern Africa, Middle East and southern Mediterranean countries. Most research has focused on the biology of the species and the development of strategies in locust control, but little is known about the place of locust pulses within food webs in which domestic herbivores and European long-distance migratory birds are also involved.

2. We evaluated the role of desert locust outbreaks in the food webs of the Sahelian region. We analysed the potential resource competition with domestic herbivores and the response of a generalist predator by assessing its diet and foraging behaviour in relation to the availability of locusts.

3. Stable isotope analyses revealed that little trophic overlap exists between desert locusts that feed on trees and shrubs and nomadic livestock that feed on grasses in the Sahelian savanna grasslands. These results suggest low resource competition with the main human resources in regions with little agricultural development. In addition, during an outbreak that occurred in winter, desert locusts were consumed by resident and longdistance migrant birds. This accounted for significant changes in the diet and foraging strategies of wintering generalist predators such as the black kite Milvus migrans.

4. Synthesis and applications. Our results raise questions about the need for spraying locust swarms in areas where economic losses are scant and wintering populations of European trans-Saharan migrant birds are high. A deeper insight into the ecological and economical role of these outbreaks is urgently needed, together with a reassessment of desert locust control in the Sahel.
\end{abstract}

Key-words: Africa, conservation, generalist predators, pesticides, primary consumers, pulsed resources, stable isotopes

\section{Introduction}

Eruptions of desert locusts Schistocerca gregaria Forskal in arid zones of Africa and the Middle Orient have been so closely intertwined with human agricultural economies that reports of catastrophes are numerous and detailed since the time of the Pharaohs (Nevo 1996).

Correspondence: José A. Sánchez-Zapata,Department of Applied Biology, Universidad Miguel Hernández, Ctra de Beniel km 3.2, 33012 Orihuela, Alicante, Spain. E-mail: toni@umh.es
The desert locust has the genetic potential to exist in either of two forms, solitaria and gregaria (Simpson et al. 2002). Desert locust plagues follow a sequence of successful breeding, starting with a non-gregarious population that, after a widespread increase in rainfall and population density, turns to a gregarious phase. A plague is characterized by many swarms (winged locusts) and nymphal (hooper) bands (Krall, Peveling \& Ba Diallo 1997). The desert locust occurs in arid regions from Senegal to India but swarms of winged insects (up to 80 million locusts $\mathrm{km}^{-2}$ ) can be found over 29 million $\mathrm{km}^{2}$ and 30 countries, including southern 
Europe and the Atlantic archipelagos. An outbreak in 2004 was the largest known since those of 1986-89. It affected the whole Sahel, from Senegal and Mauritania to the Red Sea, moved offshore from the Atlantic Ocean to the Canary and Cape Verde Islands and reached the Mediterranean Sea (http://www.fao.org, accessed March 2005).

Many ecosystems are characterized by the temporary availability of higher than normal levels or pulsed resources that may influence community structure. These have often provided new insights and promoted basic and applied ecological research (Ostfeld \& Keesing 2000; Hanski et al. 2001; Koenig \& Liebhold 2005). Desert locust outbreaks have characteristics of pulsed phenomena and might play an important role within the food web structure, by competing for food with other herbivores, providing food for predators and supporting nutrient cycles within the Sahelian ecosystems, as has been found for other insect and vertebrate eruptions (Ostfeld \& Keesing 2000, 2004).

In arid ecosystems most water and nitrogen is supplied in rain-induced pulses followed by interpulse periods with low resource supply and high stress conditions; ecological communities may be adapted to rely on such pulses (Gebauer, Schwinning \& Ehleringer 2002). Similarly, the input of materials from outside the boundaries of a food web and the role of organisms in moving materials across landscapes and ecosystems have recently been highlighted (Polis, Power \& Huxel 2004). Locusts and trans-Saharan bird migrants are an example of such organisms that transport nutrients at a continental and intercontinental scale (Lundberg \& Moberg 2003). More than $50 \%$ of European birds are trans-Saharan migrants and many of them winter in the Sahel and show long-term population declines (Sanderson et al. 2006; Thiollay 2006); their performance and life history traits are likely to be affected by resource availability in their wintering grounds (Gordo et al.2005).

However, although impressive locust outbreaks have supported important research on the biology and strategies of locust control, including forecasting and modelling habitat and evaluating chemical and biological control agents, such control has not even been subjected to a proper cost-benefit analysis (Krall, Peveling \& Ba Diallo 1997). In fact, the evaluation of the ecological effects of outbreaks has focused only on the economic benefits of predation and parasitism on locust populations (Duranton \& Lecoq 1990) and the short-term environmental impacts of pesticide spraying (Krall, Peveling \& Ba Diallo 1997). In contrast, little is known about the role of locust outbreaks in community structure and ecosystem function from which to assess the longterm effects of locust pulse control or even eradication.

In this study, our objectives were to (i) analyse resource competition between desert locust and domestic herbivores; (ii) assess the response of avian predators to locust outbreaks; and (iii) evaluate the ecological implications of desert locust control. We attempted to gain insight into how tightly locust pulses are kept within food webs in the Sahelian biomes through a natural experiment represented by the large 2004 locust outbreak. First, through measurement of stable isotopes, we compared the feeding ecology of swarms of desert locusts, a generalist herbivore (Raubenheimer \& Simpson 2003), with domestic livestock, the major vertebrate primary consumers in this region (Warren 2005). Secondly, we assessed the potential role of desert locust swarms as food for predators, and evaluated the changes in the foraging ecology of a wintering European trans-Saharan migrant, the black kite Milvus migrans Boddaert, a generalist predator considered a species of European conservation concern (BirdLife International 2004). Such predators offer the most natural way to consider temporal subsidies in food webs because they can respond both functionally and numerically to a resource pulse (Ostfeld \& Keesing 2000).

\section{Materials and methods}

Stable isotope analyses of nitrogen $\left({ }^{15} \mathrm{~N} /{ }^{14} \mathrm{~N}, \delta^{15} \mathrm{~N}\right)$ and carbon $\left({ }^{13} \mathrm{C} /{ }^{12} \mathrm{C}, \delta^{13} \mathrm{C}\right)$ were performed on freshly collected tissue samples from our study species. Abdominal tissues of desert locusts from five different swarms were collected between November and December 2004 and kept in vials containing $1.5 \mathrm{~mL} 70 \%$ ethanol. Before analysis, the ethanol was removed by successive rinsing in distilled water and freeze-drying. Hair samples of domestic herbivores and dried leaves of native plants were stored in paper envelopes until analysis. Stable carbon and nitrogen isotope assays were performed on 1-mg subsamples of homogenized materials by loading into tin cups and combusting at $1020^{\circ} \mathrm{C}$ in a Carlo Erba EA1500 NC elemental analyser on-line with a Finnigan Delta Plus XL mass spectrometer (Thermo Finnigan, Brehmen, Germany). Stable isotope abundance was expressed in standard $\delta$ notation relative to V-PDB and AIR (atmospheric $\mathrm{N}_{2}$ ) for $\mathrm{C}$ and $\mathrm{N}$, respectively. V-PDB is the Vienna international standard series (supplied by the International Atomic Energy Agency (IAEA)) as opposed to the classical calcite standard from Pee Dee Belemnite (PDB): $\delta^{15} \mathrm{~N}$ or

\section{standard}

$\delta^{13} \mathrm{C}=\left[\left(R_{\text {sample }} / R \quad\right)-1\right] \times 1000$, where $R=\left({ }^{13} \mathrm{C} /\right.$ ${ }^{12} \mathrm{C}$ or ${ }^{15} \mathrm{~N} /{ }^{14} \mathrm{~N}$ ), of the sample and standards, respectively. All samples were analysed in duplicate on different days. Usually two standards were measured every 10 samples. Based on numerous measurements of inorganic and organic international reference standards, the analytical precision was about $\pm 0 \cdot 1 \%$ o $(1 \sigma)$.

Black kites were surveyed in the Sahel of southern Mauritania and northern Mali between $15^{\circ} 0^{\prime}$ and $18^{\circ} 0^{\prime} \mathrm{N}$ and $7^{\circ} 05^{\prime}$ and $16^{\circ} 25^{\prime} \mathrm{E}$. Roadside counts were carried 
out following established methodologies (SánchezZapata et al. 2003). Systematic 30-min observations were carried out at 42 (January 2004) and 43 (NovemberDecember 2004) fixed observation points to determine environmental factors influencing the presence of black kites. Points were randomly distributed in each period and were at least $10 \mathrm{~km}$ apart. For each point we recorded information on 10 variables. We recorded presence/absence, in a radius of $2 \mathrm{~km}$, of: (i) crops, (ii) mountain slopes and (iii) marshes. To characterize potential foraging areas, we conducted additional 5-km car transects (one for each observation point) to determine the number of livestock (zebu, sheep, goat, donkey and dromedary), which were considered as (iv) total number, and (v) number of sheep and goats (the main carrion food of black kites). We also recorded (vi) presence/ absence of nomadic shepherds and (vii) villages, which were classified as absent, small $(<100$ buildings) or large ( $>100)$. (viii) Landscape composition was assessed for each observation point by accessing the GIS landuse map global land cover 2000 (Mayaux et al. 2004): (a) sandy and stony desert; (b) closed and open grassland; (c) sparse grassland; (d) crops and marshes. We also included (ix) the period (before vs. during the outbreak) and (x) time of the day (8:00-12:00 vs. 12:01-14:00).

Food habits were assessed by analysing faecal pellets collected at two (January) and three (NovemberDecember) communal roosts. Pellets were dried, their contents separated and bones, hair and feathers identified using reference collections. Desert locust individuals were counted on the basis of abdomen tip remains, as kites avoided eating the head and wings of locusts and hence they were seldom found in pellets. We also recorded any bird species seen feeding on locusts.

We used nุ̄̄̄ọōọnnn 4.1 software (Buckland et al. 2004) for fitting the detection function model and to estimate the density of black kites (individuals $\mathrm{km}^{-2}$ ). Akaike's information criterion (AIC) was employed to select the most parsimonious model (Akaike 1973).

Black kite densities were estimated through negative exponential function models with no adjustment terms ( $P=0.730$ and $P=0.269$ in January and NovemberDecember 2004, respectively). Hazard-rate function models gave similar density estimations. We fitted a generalized linear model (GLM; McCullagh \& Searle 2000) to identify those factors most likely to determine the presence of black kites at observation points (presence, 1 ; absence, 0 ; logistic and error function binomial). The response variable was compared against the abovementioned explanatory variables. All except (iv) and (v) (which evaluated number of livestock animals) were considered as fixed factors, with (a) two levels study period (before and after outbreak), hour (morning $<$ 11:00 or mid-day 11:00-15:00) and presence/absence of cultivated areas of land, marshes, mountain slopes and nomadic shepherds; (b) three levels, village (absent, small, large); and (c) four levels, large-scale habitat types (see above). Models were built through a forward stepwise procedure. As no variable had a significant influence (see above), we did not carry out further steps. Spatial autocorrelation was considered by including a spatial term representing a cubic trend surface in the modelling procedure (Legendre 1993).

\section{Results}

In January 2004, locust swarms were not detected at any of our roadside counts (covering $895 \mathrm{~km}$ ) or 42 observation points. During the outbreak (NovemberDecember 2004), four large swarms were detected along $1838 \mathrm{~km}$ of roadside counts and desert locusts were observed in $65 \%$ of the observation points $(n=43)$.

We found a significant segregation of the different species of herbivores in combined stable isotope signatures ( $\overline{\mathrm{VM}}$ ọ́ŏō̄ $\bar{M}$, Wilks' lambda $=0 \cdot 288, F_{8,148}=15 \cdot 964$, $P<0.0001$; Fig. 1). These differences were the result of both $\delta^{13} \mathrm{C}$ and $\delta^{15} \mathrm{~N}$ values (Tukey's post-hoc tests, all $P<0.001$ ) but the larger segregation was produced in relation to $\delta^{13} \mathrm{C}$. Values of $\delta^{13} \mathrm{C}$ in locust tissues were closer to those of trees and shrubs, whereas those of domestic life stock were closer to grasses.

Roadside counts of black kites carried out in January 2004, before the outbreak, resulted in 148 contacts (399 individuals); the mean group size was $2 \cdot 70(\mathrm{SE}=0 \cdot 30)$, with a resulting density of 1.42 black kites $\mathrm{km}^{-2}(1.06-$ 1.91). In November 2004, during the outbreak, we recorded 125 contacts (1283 individuals); the mean group size was $10 \cdot 26(\mathrm{SE}=2 \cdot 76)$ and the estimated density was $2 \cdot 35$ black kites $\mathrm{km}^{-2}(1 \cdot 31-4 \cdot 22)$. Most of the kites (> 90\%) were observed in the Sahelian biomes

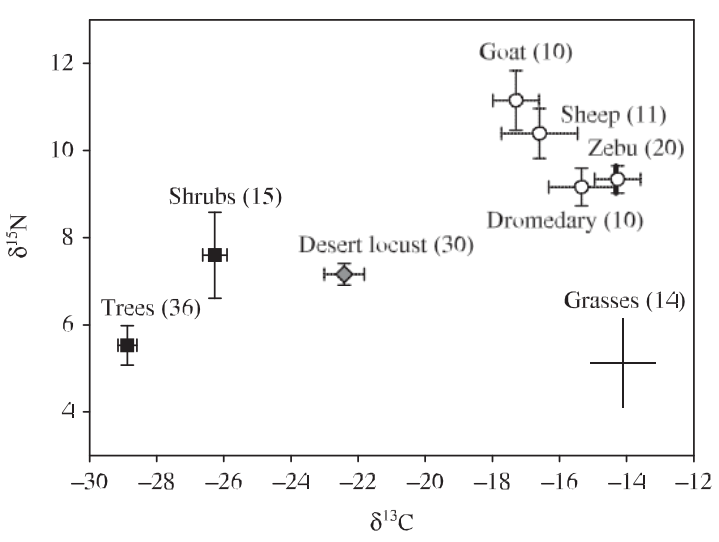

Fig. 1. Stable carbon and nitrogen isotope concentrations (mean $\pm \mathrm{SE}$, \%o) of native vegetation, desert locusts and domestic herbivores in the Sahel. Trees $(n=36)$ : Acacia raddiana, Acacia seyal, Balanites aegyptiaca, Ziziphus mauritiana, Phoenix dactyilifera, Borassus flabellifer. Shrubs $(n=15)$ : Leptademia spartum, Calotropis procera. Grasses $(n=14)$ : Cymbopogon schoenanthus, Panicum turgidum, Cenchrus biflorus, Aristida pungens. Desert locust $(n=30)$; goat $(n=10)$; sheep $(n=11)$; zebu $(n=20)$; dromedary $(n=10)$. Numbers next to crosses indicate sample sizes. 
Table 1. Maximum numbers of black kites observed within and in the immediate vicinity $(<2 \mathrm{~km})$ of towns in Mauritania and Mali were recorded. Mr, Mauritania; Ml, Mali

\begin{tabular}{lcc}
\hline Town & January 2004 & $\begin{array}{l}\text { November- } \\
\text { December 2004 }\end{array}$ \\
\hline Nouadhibou (Mr) & 0 & 0 \\
Nouackchott (Mr) & 0 & 0 \\
Alegh (Mr) & 100 & 0 \\
Kiffa (Mr) & $500-600$ & 30 \\
Ayoun el Atrous (Mr) & $300-400$ & 0 \\
Timbedgha (Mr) & 25 & 0 \\
Nema (Mr) & 50 & 0 \\
Bogue (Mr) & $<10$ & 0 \\
Nioro du Sahel (Ml) & Not visited & 0 \\
Kayes (Ml) & Not visited & 0 \\
\hline
\end{tabular}

below $17^{\circ} \mathrm{N}$, from Alegh $\left(17^{\circ} 05^{\prime} \mathrm{N} 14^{\circ} 00^{\prime} \mathrm{W}\right)$ eastwards up to Nema $\left(16^{\circ} 38^{\prime}-\mathrm{N} 7^{\circ} 15^{\prime} \mathrm{W}\right)$, in a region occupying almost $150000 \mathrm{~km}^{2}$. The probability of kite presence at the fixed observation points was independent of human habitation, habitat features and livestock resources (GLM, $P>0.05$ in all the cases). The spatial term accounting for autocorrelation included in the modelling procedure did not account for a significant part of the variation in the data.

Before the outbreak, wintering black kites scavenged mainly on domestic ungulates ( $90 \%$ of pellets; $n=46$ ) and locusts were recorded in only $4 \%$ of samples. The opposite occurred during the outbreak; locusts appeared in $100 \%$ of the pellets $(n=86)$ and domestic ungulates were absent $(\mathrm{N} \times \mathrm{M}$ exact tests, $P<0.0001$ in the two cases).

Before the outbreak, black kites were frequently found feeding in urban areas, where they exploited garbage and slaughterhouse remains. During the outbreak, towns were virtually abandoned (Table 1). Foraging group size also increased during the outbreak, with most kites concentrated in flocks of more than 100 birds (Fig. 2).

The census numbers of domestic herbivores (goat, sheep, dromedary, donkey) carried out in the two study seasons did not differ (Mann-Whitney $U$-tests, $P>0.05$ for all pairwise comparisons of species before and after the outbreak) and slaughterhouses were continuously active.

We detected two large communal roosts of kites in the vicinity of locust swarms. A sunset concentration near Hamoud (border between Mauritania-Mali) consisted of more than 5000 individuals. Another roost with up to 2000 birds was found near the oasis of Kouroudjeel (Mauritania). Tens of other raptor species, Montagu's harrier Circus pygargus Linnaeus, Eurasian marsh harrier Circus aeruginosus Linnaeus, dark chanting goshawk Melierax metabates Hartert, lanner falcon Falco biarmicus Kleinschmidt and grashopper buzzard Butastur rufipennis Sundevall, were also associated with these roosts. At least 30 bird species were observed feeding on locust groups, including 10 European
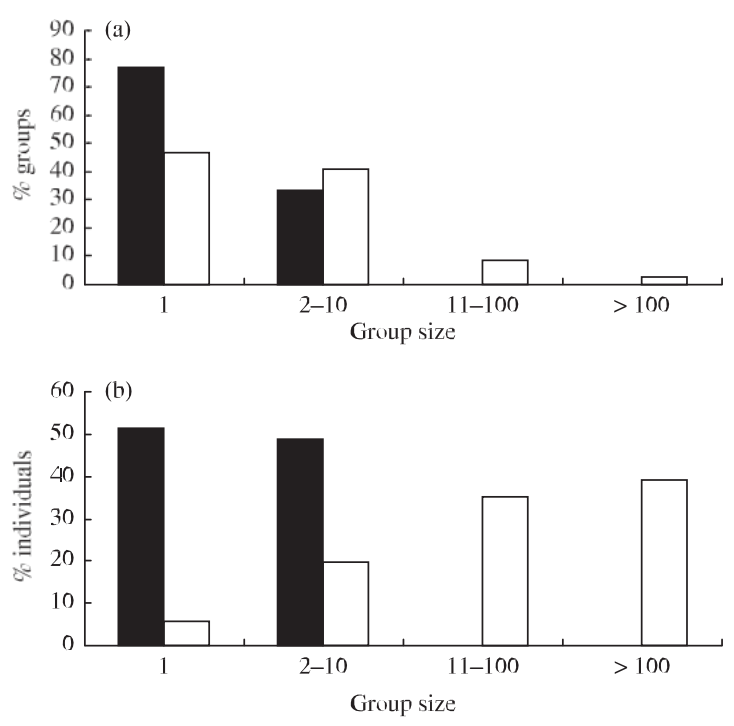

Fig. 2. Foraging group size of black kites in the Sahel. Data from observation points recorded before (filled columns) and during the desert locust outbreak (open columns). Differences were significant in (a) frequencies of observed groups $\left(X^{2}=14 \cdot 72\right.$, $P<0 \cdot 0001, n=95,68)$ and (b) frequencies of observed individuals $\left(X^{2}=301.35, P<0 \cdot 0001, n=143,561\right)$. Numbers in parentheses show sample sizes for the two study periods.

wintering species and 20 resident species (see Appendix S1 in the supplementary material).

\section{Discussion}

Our results point to little resource competition between the desert locust swarms and free-ranging domestic livestock, the main economic resource for humans in the northern Sahel (Warren 2005). Stable isotopes can track the fates of different sources of energy and materials if those sources have distinct isotopic signatures (Polis, Power \& Huxel 2004). The isotopic values associated with desert locust were also found in native plants, indicating that insects fed primarily on $\mathrm{C}_{3}$ trees and shrubs, while domestic herbivores fed on herbaceous $\mathrm{C}_{4}$ species. Only goats showed some exploitation of $\mathrm{C}_{3}$ plants (shrubs), which were probably browsed when grass was scarce (Nolan 1996). Dietary preferences of desert locust swarms could be explained on the basis of requirements for specific nutrients for physiological processes or as chemical defence against predators (Despland \& Simpson 2005). In addition, patches of perennial vegetation such as trees may be selected because of their protective cover during moulting (Culmsee 2002) and as roosting sites during the night and hottest parts of the day (Van der Werf et al. 2005). Finally, vegetation use by other gregarious grasshoppers has been considered as a response to differential plant availability, although local adaptations may also play a role (Despland, Collet \& Simpson 2000). For their part, 
nomadic shepherds probably determine the strict grazing habits shown by domestic herbivores because herds move following the availability of high-quality pastures that are often 'yellower' but richer in nitrogen (Warren 2005). In arid ecosystems, plant communities respond to increasing rainfall with explosive production of seeds and vegetative tissues (Ostfeld \& Keesing 2000) and locusts may be benefitting mostly from nitrogen-rich tissues of shrubs and trees.

During locust eruptions, black kites shifted their diet from carcasses of domestic ungulates to locusts and changed their foraging behaviour, increasing group size and leaving towns. This pattern has been described for other generalist predators that exploit pulses of resources, such as masting fruits, other insects, fish and rodents (Ostfeld \& Keesing 2000; Polis, Power \& Huxel 2004). Censuses of domestic herbivores (goat, sheep, dromedary, donkey) indicated that the shifts in the diet and foraging strategies were induced by changes in the availability of other resources.

Different studies have shown the importance of the interaction among different nutrient groups in influencing food selection and/or performance in aquatic and terrestrial organisms (Waldbauer \& Friedman 1991; Cruz-Rivera \& Hay 2003; Raubenheimer \& Simpson 2004). It is usually assumed that foraging strategies tend to be shaped by the availability of prey, with carbon (energy) as the main currency for vertebrate predators and nitrogen considered by insect nutritional ecologists as the main limiting resource (Joern \& Behmer 1998; Boersma \& Kreutzer 2002). The observed response may be modelled by the cost of searching and handling prey (MacArthur \& Pianka 1966) but also by the benefits derived from nutrient-specific requirements. In this sense, there is growing evidence that some carnivores might benefit from nutrient-specific regulatory abilities to compensate for nutritional imbalance (Evans, Stevenson \& Richards 1999; Mayntz et al. 2005).

Globally, locust pulses may have an important place within the food webs of arid subSaharan biomes. Desert locusts are primary consumers, exploiting particular food resources (trees and shrubs) that domestic livestock avoid and whose biomass during outbreaks probably surpasses, in orders of magnitude, those of vertebrate herbivores. Locusts might be moving nutrients from pulsed primary production, non-edible for most vertebrate consumers, to secondary consumers and generalist predators, playing a similar role to that described for large herbivores grazing in grassland and savanna ecosystems where they maintain the nitrogen-enriched status of intensively grazed sites (Augustine, McNaughton \& Frank 2003). The desert locust may be, in fact a 'strongly interacting species' and disruption of its natural cycles may be causing cascading dissipative transformations in ecosystems (Soulé et al. 2005). Furthermore, although locust outbreaks occur irregularly across large time intervals and broad spatial scales, lower level, more localized population build-up occurs in a seasonal cycle in most years and may also play an important ecological role.

In the short term, roosts and concentrations of birds feeding on locusts may be extremely vulnerable to pesticide aerial spraying (Mineau 2002). Control efforts in Mauritania during 2004 were primarily carried out with organophosphate chemicals (mainly chlorpyrifos and malathion; authors' personal observations) applied in small concentrated doses (referred to as ultra low volume, ULV, formulation). These compounds are potentially harmful for humans (Reichhardt 1998) and toxic effects have been demonstrated on aquatic organisms, honeybees and other insects of economic value (Mullié \& Keith 1993; Krall 1995).

In the long term, the reduction in frequency and range of outbreaks might be the result of decades of locust control campaigns (Duranton \& Lecoq 1990; Nevo 1996), although control effectiveness remains unclear (Krall 1995). A decrease in insect availability may lead to negative effects on resident predatory species that are known to consume huge amounts of locusts during the outbreaks (Culmsee 2002). In addition, a decrease in food availability for European long-distance migratory birds can be expected to have negative impacts on their subsequent reproductive success, leading to a reduction in individual fitness (Newton 2004). For example, our results reveal that the wintering black kite population has a continuous distribution along the study area and habitats, and that a large proportion of the European black kite population, estimated at around 75 000-100 000 breeding pairs (Tucker \& Heath 1994), is probably overwintering in a narrow fringe in the western Sahelian regions. In fact, the general pattern of population decline of Afro-Paleartic migrant birds seems to be largely driven by species wintering in arid open lands (Sanderson et al. 2006).

Our results reveal little resource competition between locust swarms and domestic livestock but an important role for the locust as a food resource for predators that may play a key role in semi-arid community structure and ecosystem functioning in the Sahel. In spite of this, more than 70 million US\$ were invested mainly to stop the 2004 subSaharan desert locust crisis. These efforts included spraying 3 million $\mathrm{L}$ of contact insecticides with known negative environmental effects over 12 million ha. The European Union allocated up to 12 million euros to Mauritania during the last 4 months of 2004, more than $80 \%$ of the multilateral and bilateral assistance for the current locust crisis. This contribution is almost half of the total funds allocated to this purpose in the country, and accounted for around 3\% of the total national budget (http://www.africainfomarket.org, accessed March 2005). The use of chemical pesticides against locusts is increasingly being re-evaluated because 
of its high environmental costs (Neueschwander 2004) and because its economic pay-offs are doubtful (Krall 1995). Crops occupy less than $1 \%$ of the land in Mauritania and less that 3\% in the Sahelian region of this country. Damage in the pasturelands, when reported (Lecoq 2001), seems to affect limited areas in relation to the extent of the biome. Even nomads keeping livestock in the Sahel complain that they are affected by the adverse effects of locust control campaigns, either by direct spraying over people and cattle or by ingestion of contaminated forage (Krall 1995). Although locusts did not compete with domestic animals belonging to Sahelian nomads, solitarious and gregarious locusts may invade subsistence and cash crops and compete directly with humans (Van der Werf et al. 2005).

\section{ờộ}

Emergency aid by the European Union should take into consideration the balance between detrimental ecological effects and economic benefits of locust control. A number of contradictions require investigation. On the one hand, long-distance European migrants have declined alarmingly during the last 25 years (Sanderson et al. 2006). Many of these species winter in the Sahel, where there are few protected areas and increasing human pressure results in progressive environmental degradation (Wezel \& Rath 2002). On the other hand, wintering bird populations are at risk from locust control campaigns, which are supported mainly by European grants. If control efforts were aimed at controlling fine-scale locust damage but not to the extent that locust population outbreaks were prevented entirely, it may be possible to meet the joint objectives of protecting human livelihoods, European winter migrant birds and Sahelian ecosystems.

Our results help to provide further evidence for the need of scientifically sound information as a necessary basis to rationalize desert locust control, human economies and ecosystem conservation in the Sahel. Economic development of eastern African countries has often been based on the sustainable use of highly valuable large herbivore grazed ecosystems and their megafauna of carnivores (McNaughton, Ruess \& Seagle 1988; Augustine \& Frank 2001). SubSaharan countries might also benefit from similar ecosystem-based approaches if we were able to consider locust swarms as something more than a biblical plague.

\section{Acknowledgements}

We thank F. Carro for help with the ṇn̄onọ̄ọnnn program, A. J. Fernández, L.M. Sánchez for comments and ideas during data analyses and D. Rivera for help with classification of native plants. J. R. Benítez, M. Barcell, F. Hernández, M. de la Riva and Pascal Shako and Nadia (Evasion Tours) helped with fieldwork. We are grateful to J. L. Tella, M. Carrete, F. Sergio, E. Costas, V. López-Rodas, G. Bortollotti and F. Botella. G. Bortol- lotti and Ken O'Carrolfor provided comments on earlier versions of the manuscript. David Raubenheimer, Paul Giller and an anonymous referee made valuable comments to improve the manuscript. This work was supported by the project CGL2004-00270, BBVA biodiversity award (2004), Canal Sur TV, Egmasa S.A., Son Sánchez S.A. and Ibersilva S.A.

\section{References}

Akaike, H. (1973) Information theory and an extension of the maximum likelihood principle. International Symposium on Information Theory (eds B.N. Petran \& F. Csaki), 267281. Akademiai Kiadi, Budapest.

Augustine, D.J. \& Frank, D.A. (2001) Effects of migratory grazers on spatial heterogeneity of soil nitrogen properties in a grassland ecosystem. Ecology, 82, 3149-3162.

Augustine, D.J., McNaughton, S.J. \& Frank, D.A. (2003) Feedbacks between soil nutrients and large herbivores in a managed savanna ecosystem. Ecological Applications, 13, 1325-1337.

BirdLife International (2004) Birds in the European Union, A Status Assessment. BirdLife International, Wageningen, the Netherlands.

Boersma, M. \& Kreutzer, C. (2002) Life at the edge: is food quality really of minor importance at low quantities? Ecology, 83, 252-261.

Buckland, S.T., Anderson, D.R., Burnham, K.P., Borchers, D.L. \& Thomas, L. (2004) Advanced Distance Sampling. Oxford University Press, Oxford, UK.

Culmsee, H. (2002) The habitat functions of vegetation in relation to the behaviour of desert locust Schistocerca gregaria (Forskal) (Acrididae: Orthoptera): a study in Mauritania (West Africa). Phytocoenologia, 32, 645-664.

Cruz-Rivera, E. \& Hay, M.E. (2003) Prey nutritional quality interacts with chemical defenses to affect consumer feeding and fitness. Ecological Monographs, 73, 483-506.

Despland, E. \& Simpson, S.J. (2005) Food choices of solitarious and gregarious locust reflect cryptic and aposematic antipredator strategies. Animal Behaviour, 69, 471-479.

Despland, E., Collet, M. \& Simpson, S.J. (2000) Small-scale processes in desert locust swarm formation: how vegetation patterns influence gregarization. Oikos, 88, 652-662.

Duranton, J.F. \& Lecoq, M. (1990) Ecology of locusts and grasshoppers (Orthoptera, Acrididae) in Sudanese west Africa. I. Discriminant factors and ecological requirements of acridian species. Acta Oecologica, 1, 151-164.

Evans, E., Stevenson, A.T. \& Richards, D.R. (1999) Essential versus alternative foods of insect predators: benefits of a fixed diet. Oecologia, 121, 107-112.

Gebauer, R.L.E., Schwinning, S. \& Ehleringer, J.R. (2002) Interspecific competition and resource pulse utilization in a cold desert community. Ecology, 83, 2602-2616.

Gordo, O., Brotons, L., Ferrer, X. \& Comas, P. (2005) Do changes in climate patterns in wintering areas affect the timing of the spring arrival of trans-Saharan migrant birds? Global Change Biology, 11, 12-21.

Hanski, I., Henttonen, H., Korpimäki, E., Oksanen, L. \& Turchin, P. (2001) Small-rodent dynamics and predation. Ecology, 82, 1505-1520.

Joern, H. \& Behmer, S.T. (1998) Impact of diet quality on demographic attributes in adult grasshoppers and the nitrogen limitation hypothesis. Ecological Entomology, 23, 174-184.

Koenig, W.D. \& Liebhold, A.M. (2005) Effects of periodical cicada emergences on abundance and synchrony of avian populations. Ecology, 86, 187-1882.

Krall, S. (1995) Desert locusts in Africa: a disaster? Disasters, 19, 1-7. 
Krall, S., Peveling, R. \& Ba Diallo, B.D. (1997) New Strategies in Locust Control. Bikhäuser Verlag, Berlin, Germany.

Lecoq, M. (2001) Recent progress in desert and migratory locust management in Africa. Are preventive actions possible? Journal of Orthoptera Research, 10, 277-291.

Legendre, P. (1993) Spatial autocorrelation: trouble or new paradigm? Ecology, 74, 1659-1673.

Lundberg, J. \& Moberg, F. (2003) Mobile link organisms and ecosystem functioning: implications for ecosystem resilience and management. Ecosystems, 6, 87-98.

MacArthur, R.H. \& Pianka, E.R. (1966) On optimal use of a patchy environment. American Naturalist, 100, 603-609.

McCullagh, P. \& Searle, S.R. (2000) Generalized Linear and Mixed Models. Wiley-Interscience, New York.

McNaughton, S.J., Ruess, R.W. \& Seagle, S.W. (1988) Large mammals and process dynamics in African ecosystems. Bioscience, 38, 794-800.

Mayaux, P., Bartholomé, E., Fritz, S. \& Belward, A. (2004) A new land-cover map of Africa for the year 2000. Journal of Biogeography, 31, 861-877.

Mayntz, D., Raubenheimer, D., Salomon, M., Toft, S. \& Simpson, S.J. (2005) Nutrient-specific foraging in invertebrate predators. Science, 307, 111-113.

Mineau, P. (2002) Estimating the probability of bird mortality from pesticide sprays on the basis of the field study record. Environmental Toxicology and Chemistry, 21, 14971506.

Mullié, W. \& Keith, J.O. (1993) The effects of aerially applied fenitrothion and chlorpyrifos on birds in the savannah of northern Senegal. Journal of Applied Ecology, 30, 536550.

Neueschwander, P. (2004) Harnessing nature in Africa. Nature, 432, 801-802.

Nevo, D. (1996) The desert locust, Schistocerca gregaria, and its control in the land of Israel and the Near East in antiquity, with some reflections on its appearance in Israel in modern times. Phytoparasitica, 24, 7-32.

Newton, I. (2004) Population limitation in migrants. Ibis, 146, 197-226.

Nolan, T. (1996) Animal/vegetation relations which optimize production, utilization and protection of natural resources: an African experience. African Journal of Range and Forage Science, 13, 42-48.

Ostfeld, R.S. \& Keesing, F. (2000) Pulsed resources and community dynamics of consumers in terrestrial ecosystems. Trends in Ecology and Evolution, 15, 232-237.

Ostfeld, R.S. \& Keesing, F. (2004) On the locust sang, then they drop dead. Science, 306, 1488-1489.

Polis, G.A., Power, M.E. \& Huxel, G.R. (2004) Food Webs at the Landscape Level. The University of Chicago Press, Chicago, IL.

Raubenheimer, D. \& Simpson, S.J. (2003) Nutrient balancing in grasshoppers: behavioural and physiological correlates of dietary breadth. Journal of Experimental Biology, 206, 1669-1681.
Raubenheimer, D. \& Simpson, S.J. (2004) Organismal stoichiometry: quantifying non-independence among food components. Ecology, 85, 1203-1216.

Reichhardt, T. (1998) Tight deadlines and data gaps fan the fight on pesticide safety. Nature, 396, 207.

Sánchez-Zapata, J.A., Carrete, M., Gravilov, A., Sklyarenko, S., Ceballos, O., Donázar, J.A. \& Hiraldo, F. (2003) Land use changes and raptor conservation in steppe habitats of eastern Kazakhstan. Biological Conservation, 111, 7177.

Sanderson, F.J., Donald, P.F., Pain, D.J., Burfield, I.J. \& van Bommel, F.P.J. (2006) Long-term population declines in Afro-Palearctic migrant birds. Biological Conservation, 131, 93-105.

Simpson, S.J., Raubenheimer, D., Behmer, S.T. \& Whithworth, \& Wright, G.A. (2002) A comparison of nutritional regulation in solitarius- and gregarius-phase nymphs of the desert locusts Schistocerca gregaria. Journal of Experimental Biology, 205, 121-129.

Soulé, M.E., Estes, J.A., Miller, B. \& Honnold, D.L. (2005) Strongly interacting species: conservation policy, management, and ethics. Bioscience, 55, 168-176.

Thiollay, J.M. (2006) The decline of raptors in west Africa: long-term assessment and the role of protected areas. Ibis, 148, 240-254.

Tucker, G.M. \& Heath, M.H. (1994) Birds in Europe. Their Conservation Status. BirdLife Conservation Series No. 3. BirdLife, Cambridge, UK.

Van der Werf, W., Woldewahid, G., Van Huis, A., Butrous, M. \& Sykora, K. (2005) Plant communities can predict the distribution of solitarious desert locust Schistocerca gregaria. Journal of Applied Ecology, 42, 989-997.

Waldbauer, G.P. \& Friedman, S. (1991) Self-selection of optimal diet by insects. Annual Review of Entomology, 36, 43-63.

Warren, A. (2005) The policy implications of Sahelian change. Journal of Arid Environments, 63, 660-670.

Wezel, A. \& Rath, T. (2002) Resource conservation strategies in agro-ecosystems of semi-arid west Africa. Journal of Arid Environments, 51, 383-400.

Received 27 January 2006; final copy received 20 November 2006 Editor: Paul Giller

\section{Supplementary material}

The following supplementary material is available as part of the online article (full text) from http:// www.blackwell-synergy.com.

Appendix S1. Bird species observed feeding on desert locusts showing the conservation status of European long-distance migrants 